\title{
Attitudes of the students of the College of Basic \\ Education Towards the Implementation of Moodle System in Managing University E-Courses to Enhance the Learning Process in Kuwait
}

\author{
Dr. Ahmad Alfailakawi (Corresponding author) \\ College of Basic Education \\ The Public authority for applied education and training in Kuwait
}

Received: December 1, 2020 Accepted: February 17, 2021 Published: March 5, 2021

doi:10.5296/ijld.v11i1.18378 URL: https://doi.org/10.5296/ijld.v11i1.18378

\begin{abstract}
The study aimed at investigating the Attitudes of the students of the College of Basic Education Towards the implementation of Moodle System in managing University E-Courses to Enhance the Learning Process in Kuwait. The researcher used the descriptive analytical method and then developed a questionnaire to measure students' attitudes towards the use of Moodle system in E-courses management. The study tool was divided into two domains; striving for the benefit of Moodle system and the importance of using the Moodle system, the study tool's reliability and validity were verified. The study sample consisted of (397) bachelor (male and female) students from the college of Basic Education in the Public authority for applied education and training in Kuwait. The findings revealed that the student's tendency towards using Moodle system in university E-courses management came medium. The results also showed no statistically significant differences due to the effect of sex in all domains and the full degree. The existence of statistically significant differences due to the academic level's effect in all fields and the differences came in favor of the first and second academic year in all domains and the full degree.
\end{abstract}

Keywords: Attitudes, Basic Education college Students, Moodle System, University Electronic Courses Management, Learning Process, Kuwait

\section{Introduction}

Our time is characterized by rapid change in all areas of life, including the tremendous technological revolution, and rapid progress in all areas, in addition to the increasing and 
rapid growth in the volume and quantity of information in all fields of knowledge, the importance of data produced in the previous three decades. The amount of data produced by humanity during the past centuries, and the product of the technological revolution and the rapid progress of computers, software and networks of all kinds have revolutionized the educational process, and the relentless attempt to invest this revolution in the development of academic science.

The information revolution, communications and technical explosion have created a real challenge for the various educational institutions in the Arab countries to activate this technology and benefit from its products in the development and upgrading of administrative work within its departments, so there became an urgent need required by the nature of the times. Its variables in integration and dealing with the reality of the technological explosion are an essential factor in determining the needs of the future, and a prerequisite for successful access to electronic management in educational institutions that serve the interests of the individual and facilitate administrative and educational procedures and achieve the required development goals, which are the most important. Its main objectives are to develop human knowledge in the electronic field (Ali, 2001)

Since education is the gateway to the road and the means for nations to keep up with their present and build their future, especially as attention is beginning to turn to education, it constitutes an essential dimension in state policy. The process of educational education has been crucial and has focused its attention on reaching the highest levels of quality in education (Alwale, 2005:7)

Burrello (Burrello, 2001) noted that the use of electronic technology in learning and education dramatically increases the system's efficiency in general and those working in educational and educational environments.

E-learning preserves information in various formats of drawings, images, signs, writings. It sounds with techniques that the learner interacts directly and positively to lead the learner step by step towards mastery, by placing multimedia-based information and enabling them to respond to them. In various ways, inform the learner of his success and progress in education by providing instant feedback to promote correct learning and correct wrong learning (Mohammed, Mahmoud, Younis, Sweidan, \& Aljazar, 2004: 108)

Many researchers believe that e-learning should be taken care of by making educational software part of the course, as a modern technique that facilitates the effective delivery of curriculum content, which requires the responsible authorities' attention to develop plans commensurate with rapid developments E-learning (Al-Hadifi \& Al-Daghaim, 2005: 193-194).

Trends play a central role in human life, there can be no human being without specific directions that he believes in and is passionate about and defends, and takes over as a result of its stability and stability within it on a component of his personality and trends that he may reject fiercely and aggressively, or may not be enthusiastic about it or believe in it, and may not be under He has no interest or self-preparation, and may accept it and prefer it without 
others (Eid, 2000: 20)

E-learning is therefore a way of learning using modern communication mechanisms such as computers, networks, multimedia and internet portals to communicate information to learners faster and cheaper and more costly lying to manage and control the educational process and measure and evaluate the performance of learners.

\section{Theoretical framework}

\subsection{The Concept of e-Learning}

Al-Arifi (2003: 6) defined e-learning as "providing educational content with its explanations, exercises, interaction and follow-up in part or comprehensively in the classroom or remotely by advanced software stored in computers or over the Internet".

Zaytoun (2005:24) defined him as "providing educational (electronic) content through computer-based media and networks to the learner in a way that allows him to interact actively with this content, with the teacher and his peers, whether simultaneously or insinuatingly, as well as the possibility of completing this learning in time. The place is as fast as its circumstances and abilities, as well as the possibility of managing this learning through these media." Al-Shahri (2002:38) defined e-learning as "a system of curriculum delivery (courses) over the Internet, local network, satellite, CDs, or interactive television to reach learners".

Taking advantage of the above, the researcher defined e-learning as "an educational system that provides an interactive multi-source learning environment based on computers and internet networks, as well as the possibility of managing this learning and its content electronically, which has led to the transcendence of the concept of teaching and learning walls. Classrooms have allowed the teacher to support and assist the learner at any time, simultaneously or in synchronously".

\subsubsection{Benefits of e-Learning}

The benefits of e-learning (Salem, 2004: 295)

1. E-learning provides a new culture, a digital culture that focuses on the processing of knowledge. In this culture the learner can control his or her learning by building his world when he interacts with other electronically available environments, consistent with the theory of constructive education.

2. E-learning helps provide educational opportunities for all segments of society.

3. Provides education at anytime, anywhere according to the learner's ability to achieve.

4. Contributes to the development of thinking and enriching the learning process.

5. Helps reduce the cost of education.

6. Helps the student to be independent and motivates him to be self-reliant.

7. The student learns and makes mistakes in an atmosphere of privacy (AL grab, 2003: 
28-29).

8. It can repeat and increase as much as it needs.

9. It can skip some stages that it deems easy or not.

\subsubsection{Types and Requirements of e-Learning}

The Internet provided educational and knowledge opportunities for all individuals in different ways, making the recipient look at their needs and ask them from an extensive knowledge center rather than a small classroom. Remote study is a derivative part of the e-study and in both cases the learner receives information from a place far from the teacher (source of information). The Internet must provide educational and knowledge opportunities for all individuals in different ways, making the recipient look at their needs and ask them from an extensive knowledge center rather than a small classroom. Remote study is a derivative part of the e-study. In both cases the learner receives information from a place far from the teacher (source of information), there must be a study environment to receive this type of education. There are types of e-learning mentioned by Al-Musa (Al Mezher, 2005: 36-37) As follows:

1). Simultaneous direct e-learning: Means the method and techniques of online learning to communicate and share lessons and research topics between the learner and the teacher to teach the subject such as instant chat or take lessons through so-called virtual classes.

2). Indirect or asynchronous e-learning: The learner receives intensive lessons or classes according to a planned study program in which he selects times and places that suit his or her circumstances, by employing certain e-learning methods, such as e-mail and videos, and adopts this education. On the time the learner spends to reach the skills to which the lesson is intended.

The growing demand for higher education and the wide spread of communication and information technology are influential variables in the current era, whose positive and negative effects have been reflected on the institutions of society in general and its educational and educational institutions in particular, where they are realistic examples of problems Education requires unconventional solutions (alsayf, 2009:2)

The basic idea of e-learning is to effectively design the learning and learning environment by the teacher, which focuses on the learner and his needs and abilities in a way that facilitates the learning process for any individual at any time and place using various digital learning sources to support and expand the learning process. Under the supervision of the teacher. The adoption of e-learning in university education requires an electronic learning environment with human requirements, forming a diverse team of experienced staff who collaborate in performing specific and planned functions. (Masilahi \& Muhammad, 2007: 133)

Al-Desouki (2005: 165) believes that when choosing e-learning as a university learning pattern, basic requirements must be provided, the most important of which is the special skills of both faculty member and learner, such as computer handling skills and internet services through training programs based on determining the level of skill sought by learners. And the faculty. 


\section{Macrothink}

The requirements of each system vary according to the different objectives and policies of universities. Still, there are essential components that must be available in each university that apply e-learning to be able to deal with the e-course and manage the systems, which are as classified (Mahmoud, 2007:34) to:

First: The human elements are a qualified university professor who can teach using modern techniques and design a digital course and adapt teaching methods under the characteristics of learners and the possibilities available, where his role has changed from teacher to simplified content, facilitator of educational processes and mentor It is prompt, and this requires him to acquire special knowledge, skills and experiences that we will decide on later. The learner can learn self-learning and deal in the digital environment through his computer and internet applications. Technical support staff specializing in supporting digital services, both administrative, such as electronic or educational learner registration, such as the online tetryl. In addition to the central administrative staff, the team specialized in policy-making on e-learning at the university under the policy and objectives of the university as a whole, making sure that it is going in the right direction, evaluating the previous component, and securing the infrastructure and other basic administrative procedures.

Second, the physical elements are basic equipment, such as service and computer hardware, and internet security. Electronic content and course building to bring the learner to a level of achievement, consisting of texts, images, drawings and multimedia files to enrich it, is prepared under educational design principles. Interaction interfaces are the electronic interface that guides the learner to the sites, elements of the system and ways to access it through hyperlinks and interactive electronic tools. Supporting e-learning systems, $1 \mathrm{~ms}$ and LCMS content management through a list of tools that enable the system user to control the learning process, research and quick access to text and media needed to build content.

A university that wishes to use e-learning goes through four overlapping levels or stages depending on its achievement of five main pillars: (infrastructure, digital content, laws and regulations, teaching, learning and evaluation methods, culture dissemination), Balushi and Asiri (2005:16)

\subsection{The Concept of E-Courses}

E-learning has created in different forms the development of the educational process, after the impact of technological innovations on education, and with the spread of this technology, the form of e-learning design needs to be changed in proportion to the new technology to increase its effectiveness, as the design of courses Web-based electronics need to be changed in design format to suit the new generation of the web, leading to a new educational renaissance (umasha, 2009:2)

Atmizi (2009:3) defined him as "the contents and educational electronic activities that represent every or every accredited university course and some of it received by the learner online".

Al-Shahrani (2009:48) defined the electronic course as "any course that uses computer-based educational activities and materials in its design, and to fit the e-school must be published 
online, and the web page pages are characterized by the specifications of the web page, and can be obtained by downloading from the website is published to the computer, purchased on a tablet, or received by the publisher via email".

Saleh (2005:24) considers the need to measure the quality of the e-course about the structure and sequence of activities of the content, the strategies of the education used, the objectives of the course, the interactive, the feedback, the opportunities of application, performance presentation, measurement of the effectiveness of the course, etc. Educational and educational related to screen design and interface application.

The American Society for Training \& Development (ASTD) defines the electronic course as "any type of educational or educational course sought using a software or online program." Clark (Clarke, 2004: 120) defines her as "educational materials that are an essential part of the e-learning environment and include a variety of methods used to explain lessons and information that can be called from the network while supporting interactive multimedia elements".

Based on these multiple concepts, one of the tasks to be taken into account in designing e-courses is: to identify the rationale for the use of e-learning, to identify the needs of students, to reconcile perceptions and strategies with the distance learning environment, as well as to identify the needs of learner for that kind of learning. When using the electronic course, the teacher must perform a range of roles, including (Shahrani, 2009: 48-49)

1- Determining the level of skill of his students in using computers.

2- Identify their previous requirements when using it.

3- Continue to evaluate their skills and attitudes towards the computer.

4- Diversification of educational components.

5- Providing students with technical support.

\subsubsection{E-Course Objectives and Relevance}

The objectives of the e-courses can be determined as follows (Al Mutairi, 2008: 41):

1- Designing the school course in an automated, digital and electronic way and placing it on the internet.

2- Allow learners through the available information technology to retrieve, review, and study courses located on different information networks' websites.

3- Contribute to solving the problems of admission in the stages of public and private education.

4- Eliminating the problem of traditional teaching methods.

5- Preparing the student for life and spreading the information culture.

Al-Shahrani (2009: 48) pointed out the importance of the role of the teacher in determining 
the level of skill of his students in using the computer through the electronic course, identifying their previous requirements when using it, continuing to provide their skills and attitudes towards the computer, diversifying educational components, and supporting students The electronic course has presented the teacher with modern and rapidly changing challenges, which have forced him to have more knowledge and the ability to develop himself to keep up with the times.

The concept of e-courses has emerged in recent years as science and process aimed at developing and improving learning and solving its problems through the systematic method of managing and developing the educational process in all its material and human components, and the capacity of electronic courses through what the process has witnessed. Learning from the development of technology and keeping pace with these developments so that e-learning has become an essential part of learning through e-courses at universities.

\subsubsection{Advantages of e-Courses}

E-courses have many features, including (Al-Saedi, 2009: 55)

1- The online course content is characterized by change and the teacher can add to the content and provide it with renewed sources.

2- Achieving interaction between the student and his colleagues, the student and the teacher, and non-internet-based courses do not achieve this.

3- The centering is around the student; the student is the one who controls the course of the educational process.

4- The students' activities within these courses are not specified, because they are dependent on internet connection.

5- Immediate promotion of students. The promotion may be individual between the student and the teacher or collective between the student and his colleagues, as opposed to the non-internet-based course being the individual promotion between the student and the program.

6- The web-based course is faster in development and maintenance. The scientific material is updated periodically monthly or weekly instead of non-web-based courses where it is more difficult to develop and maintain. Changing the content of the educational material needs to be re-developed.

The Texas Education Agency (TEA, 2001) has developed a tool to improve the quality of Texas students' quality on the Internet. The tool included three main groups and sub-standards organized in a calendar matrix to determine the extent to which e-courses meet quality standards, these groups The three are: the development of the components of the e-course (course design, content, educational strategies and activities, the learning community, student evaluation, and technology integration, The effectiveness of the course, academic support (technical support, student services, management reports, professional development), and financial components (education economics, service provider reputation, intellectual 
property, marketing). The agency noted that each rapporteur didn't need to meet all the criteria to be considered a high-quality rapporteur, but that the needs of learners and the educational institution should first be analyzed to determine which characteristics were more important to the target audience (Al-Saleh, 2005: 20)

\subsubsection{Types of e-Courses}

There are several types of e-courses including (Shelf, 2004: 7-10)

1- Decisions to replace traditional separation and support decisions used in conjunction with the traditional chapter.

2- Online and online courses.

3- Software that can be used in the design of courses such as: Macromedia Author ware, and programs such as: PowerPoint, Netscape Communicator can be used in the design of lessons and presentations and can be used online and without the Internet.

4- E-learning portals can be used for free such as: Nicene, discovery classroom and portals that can be used for fees such as: Blackboard, Moodle, met college, eCollege, WebCT Online Learning,

\subsubsection{The Benefits of e-Courses in Learning}

One of the most important benefits of e-courses designed specifically for the student's learning process is (Amasha, 2009, p. 16)

1- Providing a fast and secure delivery mechanism for educational media to stakeholders, for example, can be used in the distribution of traditional educational media, such as printed material for courses, guides and texts, as it converts the printed material into a direct data page.

2- Register students to access information blocks, databases on the World Wide Web, talk to their fellow students live, participate in discussion or discussion groups, send questions by e-mail to the academic supervisor or submit appointments to him electronically.

3- The academic supervisor can enter self-assessment questions, or course questions for feedback from students and learners.

4- Provide students with paths to locate information on a subject for review. In case of difficulty accessing a library or not obtaining additional information on a topic or research, any internet links the researcher to additional readings on the web within the site. Designer.

5- Provides many opportunities to reduce the student's isolation concerning time and geographical dimension.

6- Academic supervisors can be called online if needed or there is a shortage of numbers somewhere in the country and meetings with students can be organized online at a normal cost.

7- The chat rooms offer another alternative for students who lack to attend face-to-face 
sessions, so the network helps save travel time, attention and costs that allow e-mail for students and academic supervisors to communicate.

8- Course information: Here the teacher determines the subjects that students will study in the course, the pre-course requirements, the course's assessment method and the course's educational materials.

9- Course documents: Here, the teacher develops the scientific material that makes up the course content and determines the sequence of subjects to be taught by students. The content of the course consists of a written scientific material accompanied by multimedia vocabulary. The scientific material can be in the form of readings, duties, lectures, instructions for recollection, a list of terms and notes, etc. It consists of visual and audio material, images, computer simulations, and slide show. It attaches documents, notes, photos and media and organizes the course's topics in files and folders with links that lead the student to the various course classes. They can be chapters of a paper book.

10- List of external links and resources: it consists of a list of websites relevant to the decision with an accompanying comment for each site. Students can contribute to the preparation of the list.

11- Drop Homework box: students use it to send their duties to the course teacher, and the professor uses the same mechanism to return the duties to the students after reviewing, correcting and commenting on them.

12- The mechanism of preparing tests: Here the teacher prepares the weekly and quarterly tests and tests. and the questionnaires he designed.

13- Grade book: In which students are informed of their results and grades. They see how the grades are distributed to each unit of the course and use each of the course's electronic tools.

14- Statistics Course: Provides statistics on students' frequency using each component of the course component.

15- E-mail center here, the student can send private messages, a file or any attachments with the professor, a colleague, or a group of colleagues.

16- Shared files: Where the student can download, review and re-create documents, photos, spreadsheets and HTML pages from the Internet, and can carry documents prepared by a professor or student, read, review and recreate them.

17- Diary page: Here the student can record his observations or ideas, and the professor can put some duties, such as asking some questions, or commenting on some articles and asking the student to comment on them. They are modified and can be suggested to the student heading new topics.

18- Homepages profiles: A teacher and each student can have a personal page in which they put their image and information. Teachers and other students can view each other's pages.

19- Technical Support: Provides answers to user queries and provides a detailed description 
of all electronic course functions components. It also contains an e-tutorial guide that shows the teacher how to use the e-course step by step.

20- Control Panel: Contains all the editing tools needed to determine the exact details that make up the decision.

21- Before the teacher begins to use the electronic course, he must register with the company, whether it is free of charge or for a fee, registering his name, address, country of residence and electronic address, registering the name and number of the rapporteur, and giving a simplified profile. Using the control panel, the teacher enters the names of students enrolled in the course and the course's user names from assistants, administrators, and other faculty with their mailing and electronic addresses.

The course can be open to anyone from all over the world, it can be for a group of students, and students can register themselves. A teacher can place ads for students on the bulletin board, place a question or topic header, write a paragraph about it in the discussion panel, place a list of urinals under the "External Links" section, and so on. Using control panels, the teacher can make any modifications, deletions, or additions to the course components and the contents of each component .

Ryon and other persons. (Ryun, Freeman., \& Patel, 2000: 59) recommended that a plan should be developed to evaluate students' learning in e-courses before starting school, as recommended by Harrison \& Bergen (Harrison \& Bergen, 2000: 59-60)

\section{Study Problem}

Universities worldwide have sought to employ Moodle in the learning process. These universities have worked to give students and faculty an idea of Moodle and how important it is to use it and employ it. To overcome the time and place barrier between teacher and learner, develop trends towards computerization of education and employ e-learning and distance learning in the educational process, as well as the need to introduce students to the e-course and the system that is managed like Moodle to achieve the desired goals and keep up with the passengers. The researcher noted a lack in Kuwaiti universities to adopt the Moodle system for the management of electronic university courses, and to inform students to deal with them easily and easily. There is a shortage of faculty members as well, and this called for the study of the trade-off between students in their directions towards the system Moodle in learning, highlighting this important point in e-learning at Kuwaiti universities, and there are numerous studies on the trends, potency and impact of Moodle in learning, through many variables such as study (Mohammed, 2011; Dahlan, 2012; Ashour, 2009; Hassan, 2011; Jackson \& Helms, 2008; Bremer \& Brayant, 2004), the current study may be the first of its kind in Kuwait, according to the researcher's knowledge, and the current study to investigate the trends of students of the College of Basic Education towards the use of Moodle system in the management of electronic courses to enhance the process Learning in Kuwait.

\subsection{Study Questions}

1- What are the students of the College of Basic Education's trends towards the use of 
Moodle system in the management of university e-courses to enhance the learning process in Kuwait?

2 - Are there statistically significant differences at the level of indication $(\leqslant \leqslant 0.05)$ between the mathematical averages in the trends of students of the College of Basic Education towards the use of Moodle system in the management of university electronic courses to enhance the learning process in Kuwait according to the variable (gender, level of study)?

\subsection{Study Objectives}

1- Investigating the trends of students of the College of Basic Education towards the use of Moodle system to manage university e-courses to enhance the learning process in Kuwait.

2- Identify the differences between the mathematical averages in the trends of students of the College of Basic Education towards the use of Moodle system in the management of university e-courses to enhance the learning process in Kuwait according to the variable (gender, level of study).

\subsection{The Importance of Study}

The importance of the study lies as follows:

1- Identify the directions of students towards Moodle system in the management of university e-courses to enhance the learning process in Kuwait, as the use of systems to manage university e-courses may help to enhance the learning process among students in the basic college, and motivate them to go Preference for the use of Moodle system.

2- The study may help researchers to highlight e-learning and its urgency in universities and help students learn easily and flexibly through the use of Moodle in the management of university e-courses.

3-It may help the learner self-learn and enhance his or her abilities through learning and practice to use Moodle and manage e-university courses, helping facilitate the learning and learning process.

4- The development of university curriculum developers may be useful for developing educational programs and e-courses to help students develop and acquire learning skills and understand the importance of managing university e-courses and Moodle system, so they have attitudes towards them and prefer to use them.

\subsection{Study Terms}

The researcher used the following terms in the study:

Direction: "The feeling of the individual who determines his or her response to a particular subject or issue is accepted or rejected" (Zaytoun, 2004: 401).

The researcher defines the trend procedurally as: "a relatively stable acquired emotional readiness that determines the individual's feelings and behavior towards Moodle in terms of preference or lack of preference". 
Moodle: “An open source learning management system designed on educational grounds to help trainers provide an electronic learning environment, and can be used personally at the individual level” (Al Mezher, 2005: 43)

E-course: Abu khtwa (2010:7) as "a multimedia electronic learning material, provided through the computer and the Internet, providing simultaneous and simultaneous interaction between students, content, peers, and teachers ".

E-learning: Al-Sofiani (2008:7) defines it as "the best way to provide educational content for a subject in a way that aims to create a rich, partly or comprehensively multi-source, multi-source learning environment for teachers, computer networks, multiple media, software, and the Internet to access learning and learning sources in the shortest, least effort and greater benefit without restricting a particular place or time".

\subsection{Study Limits}

1 -The study was limited to investigating students' attitudes towards the use of Moodle in the management of university e-courses to enhance the learning process.

2 - The study was limited to students of the College of Basic Education in The Public authority for applied education and training in Kuwait, in the first semester 2021/2020.

\section{Previous Studies}

A study by Abu Ria and Khashan (2010) aimed at investigating the effectiveness of an educational website to teach engineering in the achievement and attitudes of ninth-grade students in Jordan. The researcher adopted the experimental method, and to test the hypotheses of the study, a web-based educational site was designed, a competency test and a questionnaire were developed, and the sample of the study consisted of (60) students from the ninth grade, divided into (experimental group and control group). The study concluded the following conclusions: the existence of statistically significant differences in the achievement of ninth grade students in engineering due to the variable method of teaching through the educational website for the benefit of the experimental group, as well as the existence of differences attributed to the variable gender in favor of males, and the absence of differences attributable To the interaction between the two variables of teaching and gender, and the existence of statistically significant differences in the trends of ninth graders towards learning through the educational website for the benefit of the experimental group, and the absence of differences due to the variable of gender, as well as the absence of differences due to the interaction of the two gender variables with Teaching method.

The study of the algrf (2008). Entitled "Requirements for activating Model E courses in the stages of public education in Saudi Arabia." This study defined e-learning, e-class rooming, e-course, learning management and learning management systems, educational content management systems, and the Model E-Course Management System. The researcher reviewed some American schools and educational areas that used the Model system in education and teacher training, and identified some of the requirements for activating the Model e courses, which included the decision of the Ministry of Education to enroll teachers 
in training courses on Use model, train trained teachers, set training objectives and content, infrastructure to activate e-courses, budget for e-learning, prepare e-learning content, activate e-courses, and provide technical support to teachers; The study made some recommendations.

Ashour Study (2009) aimed to identify Moodle's effectiveness in acquiring 3D design skills in students of the Faculty of Education Technology at the Islamic University. The researcher built an electronic course for the 3D design course and then uploaded it to the Model program and applied it to students, and used The researcher tools the study, which is an educational test consisting of (30) questions divided on five skill axes by which the researcher measures the cognitive level of students, and a note card consisting of (25) paragraphs divided into five skill axes by which the researcher measures the performance level of the students. The researcher chose a mean sample of (35) students studying in a multimedia division of the Islamic University. The researcher used the experimental method according to the nature of the head. After applying statistical treatments to the criteria, the results showed a statistical indication between the experimental group before and after the trial, and the differences were in favor of the dimensional application, meaning that the program had an impact. There were statistically significant differences between the experimental group before and after the trial. The differences were in favor of the dimensional application, which also meant that the programmed impacted. A statistically significant correlation between students' grades in 3D design performance skills and their knowledge skills for 3D design .

Jackson \& Helms conducted a study to identify students' perceptions of the effectiveness of an e-learning program offered at the undergraduate level and the need for e-course management systems. The study used a sample of 54 second-year students who were randomly selected from a U.S. university. The study used analysis (SWOT) to analyze data collected from study sample individuals. The study results indicated that the system of delivery of learning material on the website that provides the electronic course was able to provide the material according to the abilities of the individual. The results indicated a need to use management systems for electronic courses that take into account the individual needs of students .

Dahlan's study (2012) aimed to investigate the effectiveness of a Moodle system program to enroll students in basic education at Al-Azhar University the daily planning skills and attitudes towards the lessons. The researcher used the descriptive and semi-experimental structural curriculum, and built the following tools: a learning test for daily lesson planning skills, the proposed program, to learn With Moodle-enhanced software, the researcher has developed a tool to measure student trends. The study sample consisted of (60) students divided into two groups (experimental and female). The results showed no statistically significant differences between the average grades of the experimental and control group in the tribal test, and statistically significant differences between the average grades of the experimental group and the control in the dimensional test in favor of the experimental group, and the presence of statistically significant differences between the average Student trends are attributable to Moodle-enhanced program.

Mohammed's Study (2011) aimed to identify an electronic course's effectiveness to develop 
Moodle skills in graduate students and its impact on cognitive achievement. Using the descriptive and semi-experimental approach, the study tool consisted of a learning test and a questionnaire to identify achievement motivation. The study sample consisted of (20) students. The results showed shifts in learning methods from the teacher-oriented model, to the self-guided learning model, the use of ICT as a source of professional development for teachers, improved teaching methods in universities, their support for technological innovations and the activation of the role of courses. E-learning environments at the university level help grow positive trends towards their new founds, interest in using course management systems to publish courses online, and prepare students of education technology at the Faculty of Education to deal with E-learning environments.

Hassan's study (2011) was entitled "The effectiveness of an electronic course for the development of Moodle skills among graduate students in the Department of Education Technology at the Faculty of Education at The University of Benha". The sample of the study was (20) students and students for the decision of the developments of educational technology, the researcher used the curriculum semi-experimentation and worked a test of achievement of his preparation and used a measure of motivation and achievement was prepared by Farouk Abdel Fattah Musa and the subject of experimental treatment electronic course designed and developed through Moodle Learning Management System. This study's results showed the effectiveness of the electronic course and its ability to develop motivation, achievement, and cognitive achievement.

Bremer \& Brayant, 2004, aimed to compare Blackboard and Moodle as an e-learning tool from a student's perspective. The researcher used the descriptive curriculum to interpret students' responses to the questionnaire distributed to (20) students. The results showed that $80 \%$ of students preferred Moodle, while 20\% preferred Blackboard.

\subsection{Commentary on Studies}

The current study on previous studies was characterized by the fact that, according to the researcher's knowledge, it was the first of its kind in Kuwait about the subject of the study, which sought to investigate the trends of students of the College of Basic Education towards the use of Moodle system in the management of university e-courses to enhance the learning process. In Kuwait, previous studies have been used in terms of sample, methodology and statistical methods, the preparation of the current study tool, and the studies' results.

\section{Method and Procedures}

\subsection{Study Methodology}

The descriptive analytical approach, which is concerned with presenting the measured phenomenon, has been used. It is appropriate for the objectives and purposes of the current research and its variables.

The study community and its eyes

The entire study community $(17,455)$ students from the College of Basic Education in The Public Authority for Applied Education and Training in the first semester of the academic 


\section{Macrothink}

year 2021/2020, and the number of male students (5324) students and females $(12,131)$ students .

The researcher selected the sample of the study of (397) students randomly from the undergraduate students in the first academic year 2021/2020, and the sample included (152) students and (245) students in the College of Basic Education in The Public Authority for Applied Education and Training.

Table 1. Iterations and percentages by study variables Frequency categories ratio

\begin{tabular}{|l|l|l|l|}
\hline & Categories & Iteration & Percentage \\
\hline \multirow{3}{*}{ gender } & Male & 152 & 38.3 \\
\cline { 2 - 4 } & Female & 245 & 61.7 \\
\hline \multirow{2}{*}{ year } & First and second & 199 & 50.1 \\
\cline { 2 - 5 } & 3 rd and 4th & 198 & 49.9 \\
\hline & Total & 397 & 100.0 \\
\hline
\end{tabular}

\subsection{Study Tool}

After reviewing the few theoretical literature and studies that the researcher was able to obtain; 2004. The resolution consisted of (28) paragraphs, divided into two areas: the first: the quest for using a model; and the second: the importance of using the modem system. Indicators of honesty and consistency of the tool have been verified.

\subsection{Believe the Tool}

The authenticity of the tool was confirmed by presenting it to some arbitrators specializing in education technology and curriculum in its initial form, ensuring the appropriateness and affiliation of the paragraphs, the integrity of their formulation, and the adoption and modifications, and the output of the questionnaire in its final form. An example of the amendments was that the paragraph (modem training could not be trained) was modified to (Moodle training is difficult and requires considerable effort and time.) And a paragraph (I support the use of Moodle system at all educational levels) has been modified to (I support the use of Moodle system in all educational stages and courses.) The rest of the napkins were misspellings.

\subsection{The Stability of the Study Tool}

To ensure the study tool's stability, the test-retest method was verified by applying the scale, 
and reapplied two weeks later to a group outside the study sample consisting of (30) students. Then the Pearson correlation coefficient was calculated between their grades twice.

The stability factor was also calculated in the internal consistency manner by the Cronbach Alpha equation. Table 2 shows the internal consistency coefficient according to the Cronbach Alpha equation and the stability of the areas' return and the tool as a whole. These values were considered appropriate for this study.

Table 2. Cronbach Alpha Internal Consistency Coefficient and Realignment Stability of Fields and Total Grade

\begin{tabular}{|l|l|l|}
\hline Domain & Replay stability & Internal consistency \\
\hline Seeking to use a model system & 0.89 & 0.81 \\
\hline The importance of using the model system & 0.86 & 0.79 \\
\hline College degree & 0.90 & 0.84 \\
\hline
\end{tabular}

\subsection{Statistical Standard}

The Five-Year Likert Ladder was adopted to correct the study tools, giving each of its paragraphs one score out of five (strongly ok, ok, neutral, highly opposed) and represents digitally $(5,4,3,2,1)$ respectively. The following measure has been adopted to analyze the results:

From $1.00-2.33$ few

From 2.34 - 3.67 medium

From 3.68- 5.00 Large

And so,

The scale was calculated by using the following equation:

$$
\frac{\text { Uppen scale }(8)-\text { minimum soale }(1)}{\text { Nomber of eatrgontes requbrd }(8)}=1.33
$$

Then add the answer (1.33) to the end of each category.

\subsection{Study Procedures}

The researcher prepared this study according to the following steps:

The researcher prepared the theoretical framework for the study after looking at the 


\section{Macrothink}

International Journal of Learning and Development

ISSN 2164-4063 2021, Vol. 11, No. 1

theoretical literature, and identified the variables: trends, use of Moodle system, university e-courses, learning process.

The researcher conducted a survey of previous studies that dealt with each variable separately in Arab and foreign environments, and was obtained Arab and foreign studies related, and did not get the researcher studies of the variables combined - according to the researcher' science - the study is almost the first of its kind in the State of Kuwait.

The researcher processed the study tools and confirmed its sincerity and stability through the sample and after presenting it to a committee of arbitrators.

After ensuring the sincerity and stability of the tools in many ways, the researcher identified the study sample and applied the tools to it.

The researcher came up with a set of results after emptying the scans and conducting statistical analysis using appropriate statistical treatments, and then interpreted them in the light of the theoretical framework and previous studies.

Based on these findings and their interpretation, the researcher came up with a set of conclusions, made several recommendations for use in educational and psychological work, and proposed several topics for future studies.

\subsection{Statistical Treatment}

In the light of the study's questions, the researcher used the appropriate statistical treatments through analysis on SPSS. The researcher used mathematical averages and standard deviations, the Cronbach alpha internal consistency coefficient and the stability of replays and repetitions, and analyzed the quadrant contrast to show Study variables, and the use of a Chevy method of dimensional comparisons of the effect of variables.

-View and discuss the results

Question 1: "What are the students of the College of Basic Education trends towards the use of Moodle in the management of university e-courses to enhance the learning process in Kuwait"?

To answer this question, the mathematical averages and standard deviations of the basic faculty of education students' attitudes towards the use of Moodle in the management of electronic courses to enhance the learning process in Kuwait have been extracted and the table below shows this. 
Table 3. Arithmetic averages and standard deviations of the trends of students of the College of Basic Education towards the use of Moodle system in the management of university e-courses to enhance the learning process in Kuwait ranked downwardly according to the calculation averages

\begin{tabular}{|l|l|l|l|l|l|}
\hline Rank & Number & Domain & $\begin{array}{l}\text { Average } \\
\text { arithmetic }\end{array}$ & $\begin{array}{l}\text { Standard } \\
\text { deviation }\end{array}$ & Class \\
\hline 1 & 2 & $\begin{array}{l}\text { The importance of using } \\
\text { the model system }\end{array}$ & 2.93 & .811 & Medium \\
\hline 2 & 1 & $\begin{array}{l}\text { Seeking to use a model } \\
\text { system }\end{array}$ & 2.49 & .763 & Medium \\
\hline & Final class & 2.74 & .756 & Medium \\
\hline
\end{tabular}

Table 3 shows that the computational averages ranged from (2.49-2.93), where the importance of using the model system in the first place came with the highest computational average of (2.93). In contrast, the pursuit of using a model system came in last place with a mathematical average of (2.49), and the computational average for the tool as a whole. 2.74) Medium grade.

The researcher attributes the result of the current question, in which the total score is average, and with a mathematical average of (2.74) to the awareness of students the importance of using the Moodle system in the management of university courses in terms of saving time, effort and space in learning by facilitating information systems for the use of the model Moodle easily and easily, since the Moodle system provides them with a suitable learning environment to help them face difficulties while dealing with the system, but the result is moderate and less important in terms of the use of the model Moodle system, and it may seem that there are many students They find it difficult to deal with the system, and some of them find it easy to deal, and this result seems positive on the trend of students to use the Model Moodle system in the management of electronic courses, which enhances the learning process of students, the Model Moodle system helps to develop confidence to use it, Interactive communication among students, in addition to expressing their different, diverse and serious ideas to others freely, being a positive environment so that they learn in a climate in which they search for information, help achievement and motivation towards self-learning, which helps students of education technology in the Faculty of Education To deal with e-learning environments, and the need to identify and use e-course management systems and their importance as Moodle to manage and deliver e-courses according to individual capabilities and needs and seek to use them. In addition to gaining students e-learning skills and knowledge and technological learning experiences where the Moodle system displays many excites away from restriction and routine and this has a positive impact on the trend of 


\section{Macrothink}

students to use Moodle system, this result agreed with the study (Dahlan, 2012; hassan 2011; Mohammed, 2011; Ashour, 2009; algrf, 2008; Jackson \& Helms, 2008 Bremer \& Brayant, 2004).

Question 2: It states that there are statistically significant differences at the level of indication $(a \leq 0.05)$ between the mathematical averages in the directions of the students of the College of Basic Education towards the use of Moodle system in the management of university electronic courses to enhance the learning process in Kuwait according to a variable) gender, school level"?

To answer this question, the arithmetic averages and standard deviations of the trends of students of the College of Basic Education were extracted towards the use of Moodle system in the management of electronic courses to enhance the learning process in Kuwait according to the variables of gender, the level of study, and the table below shows this.

Table 4. Arithmetic averages and standard deviations of the trends of students of the College of Basic Education towards the use of Moodle system in the management of electronic courses to enhance Kuwait's learning process by gender variables, and the level of study

\begin{tabular}{|c|c|c|c|c|c|}
\hline & & & $\begin{array}{l}\text { Seeking to use a } \\
\text { Moodle system }\end{array}$ & $\begin{array}{l}\text { The importance of using the } \\
\text { Moodle system }\end{array}$ & $\begin{array}{l}\text { Total } \\
\text { score }\end{array}$ \\
\hline \multirow{4}{*}{ gender } & \multirow{2}{*}{ male } & $\mathrm{Q}$ & 2.57 & 2.99 & 2.81 \\
\hline & & $\mathrm{P}$ & .763 & .801 & .746 \\
\hline & \multirow[t]{2}{*}{ Female } & $\mathrm{Q}$ & 2.44 & 2.88 & 2.69 \\
\hline & & $\mathrm{P}$ & .760 & .815 & .760 \\
\hline \multirow{4}{*}{$\begin{array}{l}\text { School } \\
\text { level }\end{array}$} & \multirow{2}{*}{$\begin{array}{l}\text { First and } \\
\text { second }\end{array}$} & $\mathrm{Q}$ & 2.57 & 3.02 & 2.83 \\
\hline & & $\mathrm{P}$ & .775 & .785 & .743 \\
\hline & \multirow[t]{2}{*}{$3 \mathrm{rd}$ and $4 \mathrm{th}$} & Q & 2.41 & 2.83 & 2.65 \\
\hline & & $\mathrm{P}$ & .743 & .827 & .760 \\
\hline
\end{tabular}

$\mathrm{Q}=$ Average Arithmetic; $\mathrm{P}=$ Standard Deviation.

Table 4 shows an apparent variation in the arithmetic averages and standard deviations of the trends of students of the College of Basic Education towards the use of Moodle system in the 
management of university e-courses to enhance the learning process in Kuwait due to different categories of transgender people, and the level School.

The multi-binary variance analysis was used on the fields and the overall scale Table 5.

Table 5. Analysis of the multiple bilateral variation of the impact of sex and the level of study on areas and overall grade

\begin{tabular}{|c|c|c|c|c|c|c|}
\hline $\begin{array}{l}\text { Source of } \\
\text { variance }\end{array}$ & Areas & $\begin{array}{l}\text { Total } \\
\text { squares }\end{array}$ & $\begin{array}{l}\text { Degrees } \\
\text { of } \\
\text { freedom }\end{array}$ & $\begin{array}{l}\text { Average } \\
\text { squares }\end{array}$ & $\begin{array}{l}\text { Value } \\
\text { F }\end{array}$ & $\begin{array}{l}\text { Statistical } \\
\text { significance }\end{array}$ \\
\hline \multirow{3}{*}{ gender } & $\begin{array}{l}\text { Seeking to use a } \\
\text { Moodle system }\end{array}$ & 1.413 & 1 & 1.413 & 2.459 & .118 \\
\hline & $\begin{array}{l}\text { The importance of } \\
\text { using the Moodle } \\
\text { system }\end{array}$ & 1.190 & 1 & 1.190 & 1.834 & .176 \\
\hline & Total degree & 1.283 & 1 & 1.283 & 2.277 & .132 \\
\hline \multirow[t]{3}{*}{$\begin{array}{l}\text { Experience } \\
\text { The error. }\end{array}$} & $\begin{array}{l}\text { Seeking to use a } \\
\text { Moodle system }\end{array}$ & 2.575 & 1 & 2.575 & 4.483 & .035 \\
\hline & $\begin{array}{l}\text { The importance of } \\
\text { using the Moodle } \\
\text { system }\end{array}$ & 3.377 & 1 & 3.377 & 5.205 & .023 \\
\hline & Total degree & 3.020 & 1 & 3.020 & 5.361 & .021 \\
\hline \multirow{3}{*}{ Experience } & $\begin{array}{l}\text { Seeking to use a } \\
\text { Moodle system }\end{array}$ & 226.346 & 394 & .574 & & \\
\hline & $\begin{array}{l}\text { The importance of } \\
\text { using the Moodle } \\
\text { system }\end{array}$ & 255.644 & 394 & .649 & & \\
\hline & Total degree & 221.962 & 394 & .563 & & \\
\hline \multirow[t]{3}{*}{ Total } & $\begin{array}{l}\text { Seeking to use a } \\
\text { Moodle system }\end{array}$ & 230.326 & 396 & & & \\
\hline & $\begin{array}{l}\text { The importance of } \\
\text { using the Moodle } \\
\text { system }\end{array}$ & 260.203 & 396 & & & \\
\hline & Total degree & 226.258 & 396 & & & \\
\hline
\end{tabular}


Table 5 shows the following:

The lack of statistically significant differences $(=0.05)$ is due to the impact of sex in all areas and the overall degree.

This result is because the use of Moodle system in students regardless of gender comes as the system enhances the learning process through e-courses, which saves time and effort, can be learned from any place and time and this gives flexibility and ease of learning, and provides a suitable learning environment that helps to The role of the learner should be positive and effective, and communicate between them and the teachers and the system itself, and help them to self-taught themselves, and take into account the individual differences between students and this contributes to the promotion of learning through the orientation towards the use of the Model Moodle system, which manages the courses electronic them attractively and provide technical support. The current result was agreed with a study (Abu Ria and Khashan, 2010). The current finding was in agreement with a study (Bremer \& Brayant, 2004) that students in general regardless of gender preferred $80 \%$ to use Moodle.

The existence of statistically significant differences $(\mathrm{cf}=0.05)$ due to the study level's impact in all areas, and the differences were in favors of the first and second academic year in all areas and the overall degree.

This result is because first and second-year students are aware of the importance of Moodle model system in the management of e-courses due to their use in general education before they go to university, so they have experience and skills in e-learning environments that have helped to grow their orientation towards using The model system with ease and ease, and helped to develop confidence to use it, and interact with the system flexibly, the current result agreed with the study (Dahlan, 2012) based on the use of the sample of students of basic education at the university, and their orientation was positive due to the program enhanced Moodle system, in addition to Its agreement with the study (Jackson \& Helms, 2008) in terms of its second-year sample use.

\section{References}

Abu, K., \& Abdul, M. (2010). Principles of e-course design derived from learning theories and educational applications. A study presented to the conference "The Role of E-Learning in The Promotion of Knowledge Societies", held at Zain E-Learning Center, University of Bahrain, from 6-8/4/2010.

Abu, R., Mohammed, \& Khashan, K. (2010). An educational website's effectiveness to teach engineering in the achievement and trends of ninth-grade students in Jordan. Damascus University Journal of Educational Sciences, Syria, 26(3), 593-629.

Al Mezher, S. M. A. (2005). Department of E-Learning in Public Education in Saudi Arabia (proposed organizational model) ( $\mathrm{PhD}$ thesis in educational management, General Education Department, Faculty of Education, King Saud University, Riyadh).

Al-Arifi, Y. A. (2003). E-learning is a promising technique and a pioneering method. Working paper for e-learning seminar from April 12-23, Riyadh: King Faisal Schools. 
Al-Balushi, F. M., \& Assiri, I. M. (2005). E-University's foundations and its role in the success of e-learning. A working paper presented at the Second Arab Forum for Education and Education (Higher Education: Visions for the Future). Beirut: Arab Thought Foundation.

Al-Desouki, M. I. (2005). Building a program in education technology to develop faculty members and their assistants' abilities in light of training needs and the activation of quality departments. Research by the 10th Conference of the Egyptian Society for Education Technology (E-Learning Technology and Comprehensive Quality Requirements), Cairo.

AL grab, I. M. (2003). E-learning is an introduction to non-traditional training (Arab Organization for Administrative Development, Cairo).

Algrf, R. S. (2004). The extent to which faculty members at Saudi universities use e-learning: reality and aspirations. Record the symposium proceedings on the development of faculty at Saudi universities, Faculty of Education, King Saud University, Riyadh.

Algrf, R. S. (2008). Requirements for activating Model e courses in the stages of public education in Saudi Arabia. Record the proceedings of the E-Learning Forum, Ministry of Education, Riyadh, Saudi Arabia, May.

Al-Hadafi, K B. F. A., Khalid, B. I. (2005). Computer chemistry teaching on the development of scientific thinking and the trend towards chemistry in secondary school students (Egyptian Society for Curriculum and Teaching Methods, p. 103).

Ali, D. A. (2001). Internet Tools and Resources for Education and Learning, In: Computer and Education - The 16 The National Conference for Computer, 4-7 February, Riyadh: Saudi Computer Society, Pp 300-350.

Alkhlefa, H. (2008). Employ web 2.0 technologies in the service of education. Riyadh: King Saud University.

Al-Mutairi, B. B. M. (2008). The effectiveness of using educational software on first-graders in mathematics (Unpublished master's thesis in mathematics curriculum and teaching mathematics methods, Faculty of Education, Um al-Qura University).

Al-Saidi, O. B. S. (2009). Evaluating the quality of online courses in the light of educational design standards (K.A. University model). (Doctoral thesis in Teaching Techniques, Faculty of Education, Um al-Qura University).

Al-Saif, M. B. S. (2009). The availability of e-learning qualifications, constraints, and development methods from the point of view of faculty members at the Faculty of Education at King Saud University (An unpublished master's degree in arts specializing in teaching methods and technology, Faculty of Education, King Saud University).

Al-Saleh, B. B. A. (2005). E-learning and educational design: a partnership for quality. Research presented to the 10th Scientific Conference of the Egyptian Society for Electronic Learning Technology and Comprehensive Quality Requirements, 5-7/7/2005, Faculty of Education, Ain Shams University, Egypt. 
Al-Shahrani, N. B. A. N. (2009). The demands of using e-learning to teach natural sciences in higher education from specialists' point of view (Unpublished Doctoral Thesis, Department of Curriculum and Teaching Methods, Faculty of Education, Um al-Qura University, Saudi Arabia).

Al-Shahri, F. A. (2002). E-learning in Saudi schools before we buy the train did, we put the rails. Riyadh: Dar al-Knowledge.

Al-Sofiani, M. B. O. B. A. (2008). The importance and use of e-learning in teaching mathematics at the secondary level from the perspective of female teachers and educational supervisors (Unpublished master's thesis in curriculum and teaching methods, Faculty of Education, Um al-Qura University).

Alwaley, M. (2005). The level of quality of the statistics subjects included in the basic education mathematics books in Palestine in light of the National Council of Mathematics Teachers' criteria (Unpublished Master's thesis, Islamic University, Gaza).

Amasha, M. A. R. (2009). E-learning and web 2.0. Informatics Magazine, Saudi Ministry of Education, (24), 1-16.

American Society for Training \& Development (2009). E-Learning Glossary. Retrieved from http://www.astd.org/lc/glossary.htm

Ashour, M. I. N. (2009). Moodle's effectiveness in acquiring 3D design skills among Students of Education Technology at the Islamic University (Unpublished master's thesis in curriculum and education technology, Faculty of Education, Islamic University, Gaza, Palestine).

Atmizi, J. A. (2009). A flexible framework for evaluating the contents and activities of supported and integrated e-courses in Arab universities. Cybrarians magazine, (19).

Bremer, D., \& Bryant, R. (2005). A Comparison of two learning management Systems: Moodle vs Blackboard. Proceedings of the 18th Annual Conference of the National Advisory Committee on Computing Qualifications.

Burrello, C., Michael, L., Tracy, E., \& Glassman, J. (2001). A national status report on the use of electronic technology in special education management. Journal of Special Education Fall, 17. https://doi.org/10.1177/002246698301700310

Clarke, A. (2004). E-Learning Skills. New York, U.S.A, Plagrave Macmilian.

Dahlan, O. (2012). The effectiveness of a program enhanced by Moodle system gives students of basic education at Al-Azhar University the skills of daily planning of lessons and their attitudes towards it (Unpublished Master's thesis, Al-Azhar University, Gaza).

Eid, I. (2000). Social psychology. Cairo: Zahra Al-Sharq Library.

Harrison, N., \& Bergen, C. (2000). Some Design Strategies for Developing an Online Course. Educational Technology, 40(1), 57-60.

Hassan, N. E. S. (2011). An electronic course's effectiveness to develop Moodle skills in 


\section{Macrothink}

International Journal of Learning and Development

ISSN 2164-4063 2021, Vol. 11, No. 1

graduate students and its impact on cognitive and motivational achievement. Research presented at the second international e-learning conference held in February 2011 in Riyadh.

Jackson, M., \& Helms, M. (2008). Student Perceptions of Hybrid Courses: Measuring and Interpreting Quality. Journal of Education for Business, September/October, Heldref Publications, 7-13. https://doi.org/10.3200/JOEB.84.1.7-12

Mahmoud, S. S. (2007). A proposed model for the management of cultural environmental pollution in distance education. Research by the 2nd Annual Conference of the Center for Open Education (Strategic Planning for Open and Electronic Learning Systems), Ain Shams University, Cairo.

Mandora, M. M. (2004). E-learning from planning to application. A working paper presented to the second periodic meeting of the Executive Board members held in Dubai, UAE on 27 February, May 26, 2004. Arab Education Office.

Masilehi, Z. M., \& Mohammed, A. A. K. (2007). The challenges of e-university education in Egypt and the opportunities to benefit from it. The future of Arab education, 13(46), 11-228.

Mohamed, N. E. S. (2011). An electronic course's effectiveness to develop the skills of using the Moodle system among graduate students and its impact on cognitive achievement and motivation of achievement. Unpublished Master's Thesis, Faculty of Education, Binha University.

Mohammed, M., Mahmoud, H. Y., Ibrahim, Swedan, A., \& Al-Jazazar, M. (2004). Learning technology: understandings and applications. Amman: House of Thought.

Ryan, S., Scott, B., Freeman, H., \& Patel, D. (2000). The Virtual University: The Internet and Resource-Based Learning. London \& Sterling (U.S.A.): KOGAN PAGE

Salem, A. (2004). E-learning technology. Riyadh: Al-Rashed Library.

Zaytoun, H. (2005). A New Vision in Education :"E-Learning": Concept- Issues - Application - Evaluation, Saudi Arabia. Riyadh: The Saltia House of Education.

Zaytoun, K. A. H. (2004). Education technology in the ict age. I2, Cairo: The Science of the Book. 


\section{Supplement (1)}

The calculation averages and standard deviations of the study sample estimates were calculated on the paragraphs of each area, where they were as follows:

Area 1: The importance of using the model system

Table(-) Computational averages and standard deviations of paragraphs related to the importance of using the model system are ranked downwardly by calculation averages

\begin{tabular}{|c|c|c|c|c|c|}
\hline $\begin{array}{c}\text { Ran } \\
\mathbf{k}\end{array}$ & $\begin{array}{l}\text { Numbe } \\
\quad r\end{array}$ & Paragraphs & $\begin{array}{l}\text { Average } \\
\text { arithmet } \\
\quad \text { ic }\end{array}$ & $\begin{array}{c}\text { Standar } \\
\text { d } \\
\text { deviatio } \\
n\end{array}$ & Class \\
\hline 1 & 1 & $\begin{array}{l}\text { I wish to turn my traditional courses into } \\
\text { Moodle. }\end{array}$ & 3.48 & 1.199 & $\begin{array}{l}\text { Mediu } \\
\mathrm{m}\end{array}$ \\
\hline 2 & 6 & $\begin{array}{l}\text { Moodle training is difficult and requires a } \\
\text { lot of effort and time. }\end{array}$ & 3.44 & 1.141 & $\begin{array}{l}\text { Mediu } \\
\mathrm{m}\end{array}$ \\
\hline 3 & 9 & $\begin{array}{l}\text { I hope I don't study any course through } \\
\text { Moodle. }\end{array}$ & 3.15 & 1.196 & $\begin{array}{l}\text { Mediu } \\
\mathrm{m}\end{array}$ \\
\hline 4 & 5 & $\begin{array}{l}\text { I help my colleagues who have difficulties } \\
\text { in training on Moodle. }\end{array}$ & 2.52 & 1.238 & $\begin{array}{l}\text { Mediu } \\
\mathrm{m}\end{array}$ \\
\hline 5 & 8 & I will advise my colleagues to use Moodle. & 2.46 & 1.258 & $\begin{array}{l}\text { Mediu } \\
\mathrm{m}\end{array}$ \\
\hline 6 & 3 & I don't want to use Moodle. & 2.32 & 1.353 & A few. \\
\hline 7 & 2 & $\begin{array}{l}\text { Make sure you learn everything about } \\
\text { Moodle. }\end{array}$ & 2.27 & 1.391 & A few. \\
\hline 8 & 11 & $\begin{array}{l}\text { I avoid participating in any e-learning course } \\
\text { (Moodle system). }\end{array}$ & 2.21 & 1.435 & A few. \\
\hline 9 & 4 & $\begin{array}{l}\text { I hope to have a variety of sources in } \\
\text { Moodle. }\end{array}$ & 2.09 & 1.257 & A few. \\
\hline 10 & 12 & $\begin{array}{l}\text { I am seeking to use Moodle to gain more } \\
\text { skills and experience in e-learning. }\end{array}$ & 2.06 & 1.243 & A few. \\
\hline
\end{tabular}




\begin{tabular}{|c|c|l|c|c|l|}
\hline 11 & 7 & $\begin{array}{l}\text { I discuss with my colleagues how to use } \\
\text { Moodle. }\end{array}$ & 1.99 & 1.201 & A few. \\
\hline 12 & 10 & $\begin{array}{l}\text { I would like to have my master's field on } \\
\text { Moodle. }\end{array}$ & 1.88 & 1.224 & A few. \\
\hline & & $\begin{array}{l}\text { The importance of using the model system } \\
\text { Tim }\end{array}$ & 2.49 & .763 & $\begin{array}{l}\text { Mediu } \\
\mathrm{m}\end{array}$ \\
\hline
\end{tabular}

\section{Supplement (2)}

The second area: the quest to use a model system

Table(-) Computational averages and standard deviations of paragraphs related to the scope of the quest to use a model system ranked downwardly by calculation averages

\begin{tabular}{|c|c|l|c|l|l|}
\hline $\begin{array}{l}\text { Ran } \\
\mathbf{k}\end{array}$ & $\begin{array}{l}\text { Numbe } \\
\mathbf{r}\end{array}$ & Paragraphs & $\begin{array}{l}\text { Average } \\
\text { arithmeti } \\
\mathbf{c}\end{array}$ & $\begin{array}{l}\text { Standar } \\
\mathbf{d} \\
\mathbf{d e v i a t i o} \\
\mathbf{n}\end{array}$ & Class \\
\hline 1 & 14 & $\begin{array}{l}\text { Moodle is one of the most powerful course } \\
\text { management systems in e-learning. }\end{array}$ & 3.50 & 1.132 & $\begin{array}{l}\text { Mediu } \\
\mathrm{m}\end{array}$ \\
\hline 2 & 18 & $\begin{array}{l}\text { The Moodle system provides multiple means } \\
\text { of communication between students and } \\
\text { employees simultaneously rather than } \\
\text { simultaneously. }\end{array}$ & 3.48 & 1.129 & $\begin{array}{l}\text { Mediu } \\
\mathrm{m}\end{array}$ \\
\hline 4 & 23 & $\begin{array}{l}\text { The features and features of Moodle will help } \\
\text { spread e-learning. }\end{array}$ & 3.46 & 1.244 & $\begin{array}{l}\text { Mediu } \\
\mathrm{m}\end{array}$ \\
\hline 5 & 24 & $\begin{array}{l}\text { Moodle makes students more active and } \\
\text { active through their activities. }\end{array}$ & 3.43 & 1.214 & $\begin{array}{l}\text { Mediu } \\
\mathrm{m}\end{array}$ \\
\hline 6 & 26 & $\begin{array}{l}\text { I get bored when I use Moodle. } \\
\text { finished the activities assigned to it. }\end{array}$ & 3.43 & 1.165 & $\begin{array}{l}\text { Mediu } \\
\mathrm{m}\end{array}$ \\
\hline
\end{tabular}




\section{Ml Macrothink}

International Journal of Learning and Development

ISSN 2164-4063 2021, Vol. 11, No. 1

\begin{tabular}{|c|c|c|c|c|c|}
\hline 7 & 21 & $\begin{array}{l}\text { Moodle is very flexible in managing } \\
\text { e-courses. }\end{array}$ & 3.22 & 1.126 & $\begin{array}{l}\text { Mediu } \\
\mathrm{m}\end{array}$ \\
\hline 8 & 19 & $\begin{array}{l}\text { I am proud to have a Moodle system at my } \\
\text { university. }\end{array}$ & 3.21 & 1.231 & $\begin{array}{l}\text { Mediu } \\
\mathrm{m}\end{array}$ \\
\hline 9 & 25 & $\begin{array}{l}\text { The Moodle system excites and attracts my } \\
\text { attention. }\end{array}$ & 3.17 & 1.213 & $\begin{array}{l}\text { Mediu } \\
\mathrm{m}\end{array}$ \\
\hline 10 & 22 & $\begin{array}{l}\text { Learning through Moodle will revolutionize } \\
\text { e-learning. }\end{array}$ & 2.66 & 1.418 & $\begin{array}{l}\text { Mediu } \\
\mathrm{m}\end{array}$ \\
\hline 11 & 28 & $\begin{array}{l}\text { The Moodle system is complex, difficult to } \\
\text { handle and stressful. }\end{array}$ & 2.65 & 1.467 & $\begin{array}{l}\text { Mediu } \\
\mathrm{m}\end{array}$ \\
\hline 12 & 27 & $\begin{array}{l}\text { Traditional education is much better than } \\
\text { e-learning through Moodle. }\end{array}$ & 2.62 & 1.459 & $\begin{array}{l}\text { Mediu } \\
\mathrm{m}\end{array}$ \\
\hline 13 & 13 & Learning through Moodle is a waste of time. & 2.60 & 1.533 & $\begin{array}{l}\text { Mediu } \\
\mathrm{m}\end{array}$ \\
\hline 14 & 17 & $\begin{array}{l}\text { I expect my e-learning skills to increase with } \\
\text { the Moodle system. }\end{array}$ & 2.25 & 1.448 & A few. \\
\hline 15 & 16 & $\begin{array}{l}\text { Learning through the Moodle system does not } \\
\text { take into account individual differences } \\
\text { between students. }\end{array}$ & 1.90 & 1.246 & A few. \\
\hline 16 & 15 & $\begin{array}{l}\text { I support the use of Moodle in all educational } \\
\text { stages and courses. }\end{array}$ & 1.86 & 1.235 & A few. \\
\hline & & Seeking to use a model system & 2.93 & .811 & $\begin{array}{l}\text { Mediu } \\
\mathrm{m}\end{array}$ \\
\hline
\end{tabular}

\section{Copyright Disclaimer}

Copyright for this article is retained by the author(s), with first publication rights granted to the journal.

This is an open-access article distributed under the terms and conditions of the Creative Commons Attribution license (http://creativecommons.org/licenses/by/4.0/). 